\title{
CAPACITY BUILDING FOR COMMUNITY AWARENESS ON CORPORATE SOCIAL RESPONSIBILITY OF OIL COMPANIES FOR SUSTAINABLE COMMUNITY DEVELOPMENT IN NIGERIA
}

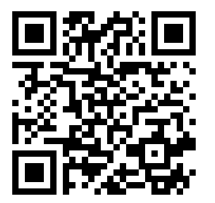

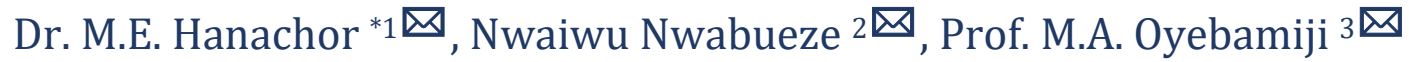 \\ ${ }^{* 1,2,3}$ Department of Adult \& Non-Formal Education, Faculty of Education, University of Port \\ Harcourt, Nigeria
}

DOI: https://doi.org/10.29121/granthaalayah.v9.i2.2021.3380

Article Type: Research Article

Article Citation: Dr. M.E. Hanachor, Nwaiwu Nwabueze, and Prof. M.A. Oyebamiji. (2021). CAPACITY BUILDING FOR COMMUNITY AWARENESS ON CORPORATE SOCIAL RESPONSIBILITY OF OIL COMPANIES FOR SUSTAINABLE COMMUNITY DEVELOPMENT IN NIGERIA. International Journal of Research -GRANTHAALAYAH, 9(2), 281-290. https://doi.org/10.29121/granthaa layah.v9.i2.2021.3380

Received Date: 25 January 2021

Accepted Date: 25 February 2021

Keywords:

Capacity Building Programmes Corporate Social Responsibility Sustainable Community Development

\begin{abstract}
Exploration activities of Oil companies in most communities in Nigeria have negatively impacted on the environment where they are performing their business activities without adequate compensation to the community people. Such negative impacts include; gas flaring, oil spillages, noise and air pollution and so on and these affect the flora and fauna. Even when compensations are paid, they are not commensurate to the damage and this result in communal conflicts, overheated and prolonged agitations, frustrations, loss of lives and properties and consequently unhealthy relationship between the oil companies and their host communities. This is basically as a result of community people possessing little or no awareness of the terms of the corporate social responsibility to be performed by all participating stakeholders especially the oil companies. This paper therefore examines how capacity building programmes can be employed as a means to equipping and increasing the awareness of community people with necessary information on corporate social responsibility of oil companies for sustainable community development in Nigeria. Some of such programmes include adult literacy education, extension education, conferences, seminars, talk shows, education consultancy just to mention a few. The paper therefore suggests that community members should be adequately informed on existing aspects of the corporate social responsibilities of oil companies operating in their locality and that these oil companies perform their corporate social responsibility to their host communities effectively in order to foster sustainable community development.
\end{abstract}

\section{INTRODUCTION}

Every oil company, whether private or publicly owned, is domiciled within a community be it rural or urban and this is the case all over the world including Nigeria. Some oil companies in Nigeria include; Exxon Mobil, Shell Petroleum Development Company (SPDC), Agip, Total, just to mention but a few. As these oil companies carry out their oil exploration and other activities within their host communities, the environment is degraded and polluted and this affects the existence of flora, fauna and human activities. Some of these devastating experiences includes gas flaring and oil spillage living community members in a state of suffering and confusion.

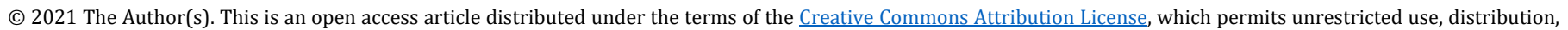
and reproduction in any medium, provided the original author and source are credited. 
Capacity Building for Community Awareness on Corporate Social Responsibility of Oil Companies for Sustainable Community Development in Nigeria

Community people as a result of ignorance of the corporate social responsibilities of the companies to them go into agitations and most times asking for meagre cash compensations which cannot make up for the huge degradations, environmental pollution and lost of community resources. They wallow in penury while these oil companies and their staff live in affluence and abundance. Most times, community representatives to these oil companies are bought over with some cash gratifications and they drop their move to asking the oil companies give back and positively impact the communities where they live and do their business. These actions of ignorance by host communities has led to communal crises, destruction of lives and properties and disruption of the activities of oil companies. Sometimes, community members become over demanding on oil companies operating within their communities as some of them are not employable due to lack of possession of relevant skills and competencies. This category of community members act like these companies should provide all their needs.

Some of the corporate social responsibility of the oil companies are; construction of health care centres, schools, provision of electricity, pipe borne water, bus stops, markets stalls/shops, construction and maintenance of roads, awards of scholarships to deserving students, donations to orphanages and home for the elderly, organise skill acquisition programmes and provision of employment opportunities to qualified community members, just to mention a few, while community people should ensure that the community is very conducive for the oil companies to perform their business without hiccups. This process of giving back to host communities by oil companies and other business ventures is what is referred to as corporate social responsibility.

Corporate social responsibility is simply a way for companies to take responsibility for the social and environmental impacts of their business operations (Business News Daily, 2018). It is a business approach that contributes to sustainable development by delivering economic, social and environmental benefits for all stakeholders. This suggests that no community where the activities of oil companies are eminent is supposed to be neglected or abandoned due to the hazards of their business activities without due compensation.

It is sad to mention that even in contemporary times, most community members are not aware of or do not possess adequate information of what corporate social responsibility is all about; what it entails and how to go about it. Most of them are not aware of what the term corporate social responsibility refers to as a result of their limited access to organised awareness programmes on corporate social responsibility. It therefore becomes imperative to employ capacity building programmes in order to increase awareness and enlighten community members on the corporate social responsibility of oil companies in order to foster sustainable community development.

\section{CORPORATE SOCIAL RESPONSIBILITY}

Corporate social responsibility (CSR) refers to how companies manage their business processes to produce an overall positive impact on the society. CSR encompasses sustainability, social impact and ethics and should be done correctly. This suggests that CSR must be carried out in a manner that it does that not violate the rules and regulations guiding it so that all relevant stakeholders are adequately carried along in the scheme of things.

The World Business Council for Sustainable Development (2016) defined corporate social responsibility as the continuing commitment of corporate organisations to behave ethically and contribute to economic development of their host communities, while improving the quality of life of their workforce and their families as well as the local community and the community at large. Corporate social responsibility does not only concern itself with the welfare of the company staff but that of the host communities. This definition therefore disagrees with the situation where oil company workers live in so much financial abundance while the host community members wallow in abject poverty. This situation is often witnessed in most oil rich rural communities in the Niger Delta Area of Nigeria. CSR advocates that as the oil company's employees' welfare is given appropriate consideration, that of the host community members should also be considered and the society at large as this has the ability to potentiate a peaceful and harmonious relationship between business owners and community members in Nigeria.

Corporate social responsibility is also referred to as Corporate sustainability, sustainable business, corporate conscience, corporate citizenship or responsible business. Carroll (1991), defines CSR as a company's sense of responsibility towards the community and environment both ecologically and socially in which it operates. Companies express this citizenship through their waste and pollution reduction processes by contributing to educational and social programmes with adequate earning returns and employed resources. The definition was supported by Sheehy (2014). Sheehy further defined CSR as an international private business self-regulation. 
According to Lee and Kotler (2013), corporate social responsibility includes six types of corporate social initiatives which includes:

- Corporate philanthropy- this comes in form of company's donation to charity, such as cash, goods, and services or corporate foundation;

- Community volunteering- company-organised volunteer activities, sometimes while an employee receives pay for pro-bono work on behalf of a non-profit organisation

- Socially-responsible business practices- ethically produced products which appeal to a customer segment;

- Cause promotions- company funded advocacy campaigns;

- Cause-related marketing- donations to charity based on product sales and

- Corporate social marketing- company funded behaviour-change campaigns.

\section{CAPACITY BUILDING}

Certain amount of capacities is embedded in people and communities. There is no community without capacity but often the capacities need to be developed. It is therefore important to note that at the heart of capacity building is community people. Healthy communities are made up of healthy people and families. The creation of healthy environment will encourage healthy economies and sustainable development. It takes capacity to do this as well as good leadership, a viable plan, motivation and the support of the community. This means that it takes capacity to build capacity and it takes a well taught out process to start both capacity building and effective community development.

Capacity is an elusive concept. It is described as a process and an outcome; as a dynamic and multidimensional. Capacity can be said to develop in stages of readiness which indicate improvement or decline. In any case, capacity exists for the purpose of performing certain action or enabling performance. Goodman (1998) describes capacity as the ability to carry out stated objectives.

Capacity is simply the ways and means needed to do what has to be done. It is much broader than simply skills, people and plans. Capacity includes commitment, resources and all that is brought to bear on a process to make it successful. Capacity therefore includes the following components as stated by Frank \& Smith in Oyebamiji and Nwabueze (2020):

1) People who are willing to be involved

2) Skills, knowledge and abilities

3) Wellness and community health

4) Ability to identify and access opportunities

5) Motivation and the wherewithal to carry out initiatives

6) Infrastructure, supportive institutions and physical resources

7) Leadership and the structures needed for participation

8) Economic and financial resources

9) Enabling policies and systems

Capacity building is the process by which individuals and organisations obtain, improve and retain skills, knowledge, tools, equipment and other resources needed to do jobs competently or to a greater capacity or scale. Capacity building and capacity development are often used interchangeable. Sometimes, it is referred to as community capacity building because it has to do with empowering a group of people to acquire relevant skills and information necessary for improving their living condition.

Capacity building often refers to strengthening the skills, competencies and abilities of people and communities in small businesses and local grassroots movements so as to achieve their goals and potentially overcome the causes of their exclusion and suffering. Many organisations interpret community capacity building in their own ways and focus on it rather than promoting two-way development in developing nations. Fundraising, training centres, exposure visit, office and documentation support, on the job training, learning centres and consultants are all forms of capacity building. In order to avoid or prevent international aid for development from becoming perpetual dependency, developing nations are adopting strategies provided by the organisations in the form of capacity building. 
Capacity Building for Community Awareness on Corporate Social Responsibility of Oil Companies for Sustainable Community Development in Nigeria

The United Nations International Strategy for Disaster Reduction (UNISDR) (2016) defines capacity building as the process by which people, organisation and society systematically stimulate and develop their capability over time to achieve social and economic goals, including through improvement of knowledge, skills, systems and institutions, within a wider social and culturally enabling environment. This definition further explains that capacity building is a process broken into phases, not a one stop crash programme, with each phase having its goals. Therefore, a thorough assessment of each phase to ascertain the achievement of the prescribed goals will pave way for the next phase otherwise, such phase should perhaps be repeated as this will provide participants with adequate information for effective discharge of their duties and responsibilities especially in their various communities.

The United Nations Development Programme (UNDP) (2011), defines capacity building as a long-term continual process of development that involves all stakeholders; including ministries, local authorities, non-governmental organisations, professionals, community members, academics and more. Capacity building uses a country's human, scientific, technological, organisational and institutional and resource capabilities. The goal of capacity building is therefore, to tackle problems related to policy and methods of development, while considering the potential, limits and needs of the community concerned.

Community capacity building according to Craig (2007) is concerned with promoting the capacity of community to develop, implement and sustain their own solutions to problems in a way that helps them shape and exercise control over their physical, social, economic and cultural environments. It is the continuous process required to foster the pride and appropriate local leadership that allows communities, through their members to take responsibility for their own development, (Verity, 2007).

Merinoa and Carmenadoa (2012) defined capacity building as the process by which individuals, groups, organisations, institutions and societies increase their abilities to perform core functions, solve problems, define and achieve objectives; and understand and deal with their development needs in a broad context and in a sustainable manner. Capacity building therefore empowers people with a broadened horizon and perspective to life challenges and needs, thereby helping people to change their approach to situations around them. This has the potential of sustaining developmental programmes for improved living.

Laverack and Thangphet (2009) suggests that capacity building is a process that increases the assets and attributes that a community is able to draw upon to improve their lives. Saegert as cited in Patrick and Ijah (2017) explains that community capacity building emphasises development of relationships within and outside the community and the use of community assets to leverage assets from outside to solve common problems. Hence, community capacity building focuses on relationship building, leadership development and developing people's skills, sustaining stakeholders' engagement, developing a sense of common purpose, an action agenda and increasing local institutional capacity.

Capacity can be perceived as a moving target. At any given time, capacity can improve or decline. It often develops in stages that indicate improved readiness to influence performance (Goodman, 1998). Capacity building, therefore, is an ongoing process (the development of abilities), whose stages can be measured as "development outcomes" through monitoring and evaluation. The dynamic nature of capacity is often a reflection of the many different forces that influence its development or decline.

From the foregoing, it can be deduced that capacity building focuses on specific objective or goal, it is dynamic, multidimensional, and it depends on the context and facilitates change in behaviour. When capacities of communities are built or developed, it always has a greater impact on many aspects of community development. This is because, emphasis is placed on existing strength and abilities rather than being overwhelmed by problems or feelings of powerlessness. When people's capacity is developed within a community, it implies that community are active, interested and participating in what is going on. Built capacities of community members gives them ample opportunities to question, challenge and debate what should be done rather than complaining that nothing will ever change. Capacity building makes community members to get involved, identify key issues and taking actions.

\section{DOMAINS FOR COMMUNITY CAPACITY BUILDING FOR SUSTAINABLE COMMUNITY DEVELOPMENT}

Oyebamiji and Nwabueze (2020) citing Patrick and Ijah posit seven (7) domains for community capacity building for sustainable community development. They are as follows: 


\subsection{LEADERSHIP DOMAIN}

One key component for the smooth functioning of any system, organisation or community is leadership. It forms one of the domains of capacity building, especially within the community sphere.

According to Rabinowitz (2011), to ensure sustainability of any community development project or programme leadership is the most important resource. This is because leaders make things happen, they have vision, take initiative, influence people, make proposals, organise logistics, solve problems, follow up and take responsibility.

\subsection{POLITICAL DOMAIN}

Wildemeersch (2014), refers to political domain as creating conditions of democratic participation by mobilising the capacities of different actors involved, thereby empowering the community in terms of synergy, identification and strengthening of the social fabric through increasing participation in community development programmes. It goes beyond providing necessary information and motivation for political action for disadvantaged persons in community but also having the cultural and physical space to make political action real.

Political domain of capacity building for citizens participation also empowers citizens to take control of their own socio-economic and political development, understand how government works or the governance process and developing the core values of democracy such as freedom, justice, solidarity and tolerance for others. Communitybased adult education is one of the approaches that could empower citizens for political action.

\subsection{ECONOMIC DOMAIN}

Economic domain is vital as the source of livelihood and employment opportunities of any given community. Developing the economic domain will ensure the recruiting of new businesses, retaining and expanding of existing businesses in the community and facilitating new business start-ups. Building the economic capacity of citizens for improved participation in community development programmes also involves building the community to market itself to varieties of entities such as new firms, existing firms, non-profit organisations, tourists, new residents, restaurant chains and consequently creating a culture of entrepreneurship among community members.

Economically, capacity building provides people with the opportunity of acquiring new skills, information and competencies for improving their economic life and that of their communities.

\subsection{PARTNERSHIP DOMAIN}

Partnership domain of capacity building explains the need for communities to be trained and exposed to the need to partner with various stakeholders, whether individuals, government and non-governmental agencies for the purpose of fostering sustainable community development.

\subsection{CULTURAL DOMAIN}

This domain is referred to as the totality of the way of life of a people. Cultural dimension is a major lacuna in the development of a people. Therefore, building the cultural domain of the people is very imperative as the understanding gained about the people is necessary for building the social capital of the community and thereby motivate the people to be actively participate in community development programmes. Activities such as recreational events, cultural festivals, music and spiritual songs, local and traditional sports, religious practices are some capacity building programmes that could motivate citizens to participate in community development programmes.

\subsection{ECOLOGICAL DOMAIN}

This domain refers to the environment or ecosystem. This implies that economic activities must be done in line with global best practices such that it does not adversely affect the ecosystem. Some of such activities include oil 
Capacity Building for Community Awareness on Corporate Social Responsibility of Oil Companies for Sustainable Community Development in Nigeria

exploration, mining, felling of trees, flaring of gas and disposal of toxic/industrial wastes. The consequence is that if the ecosystem is safe, then its inhabitants will be safe but where it is not, then it will not be habitable for community members thereby exposing them to catastrophic diseases, depletion of the ozone layers, desertification, flood, gully erosion and so on.

\subsection{INFRASTRUCTURAL DOMAIN}

Provision of basic health facilities/services, affordable good housing, sanitation infrastructure and creation of equity groups are some of the areas where citizens capacities are built for improved participation in community development programmes. When community members through self-help or networking with government and nongovernmental agencies to set up, it spurs up their living conditions and consequently allows for better societies.

\section{CAPACITY BUILDING PROGRAMMES FOR CORPORATE SOCIAL RESPONSIBILITY}

For community members to be adequately aware of the corporate social responsibilities of oil companies within their communities for better co-existence and improved service delivery, there is the need for effective engagement of community members in capacity building programmes so as to enlighten them. Such programmes as stated by Frank and Smith (2014) include:

- Conferences- Educational conferences where issues bordering on CSR should be regularly organised for community people so as to increase their awareness on the subject and thereby equipping them with necessary information. This will go a long way in exposing them to current information on CSR in order to handle its related challenges appropriately.

- Seminars- When people are not adequately informed about an issue; their approach to it will always be limited. Government and Non-governmental agencies should organise constant seminar on CSR for community members to improve their consciousness and better their attitude towards it.

- Talk-shows- This is an adult education programme where resource persons are invited and strategic educative issues are discussed thereafter providing opportunity for participants to ask questions and get answers to satisfy their curiosity. Talk shows on CSR should be organised for community members to assist them get enlightened on CSR issues in order to foster sustainable community development

- Enlightenment campaigns- Corporate bodies and government agencies such as National Orientation Agency should put together enlightenment programmes on CSR for increased awareness.

- Townhall meetings- Townhall meeting is a situation where all participating stakeholders come together on a level-play-ground to discuss pertinent issues with the view to proffering solutions for improved service delivery and harmonious relationships. Oil companies, community leaders and their members should regularly organise this kind of educative forum where the grievances and the misconceptions of all stakeholders are discussed amicably. This possesses the potency of enlightenment on CSR

- Adult Literacy programmes- Adult literacy programmes equip citizens with the basic literacy skills such as reading, writing and computing. Whenever community people possess these basic skills, it becomes easier for them to become functional members of society. This implies that they go out by themselves and source for relevant materials on CSR and study in order to improve their knowledge and attitude and consequently sustain community development in their locality and the world at large.

- Information and communication technology- Through information and communication technology (ICT), people are able to access several information from different people in different parts of the world thereby making the world a global village. Community people through the use of ICT can compare what goes on in their locality and that of others thereby raising their consciousness on the happenings around the world especially on CSR related issues for sustainable community development

- Adult educational consulting- Many persons have studied CSR and could be referred to as experts in that field. Such persons or organisations could be consulted to solve challenges relating to CSR and improve the awareness of community people on its associated problems 
- Extension Education Programme- Universities and other educational institutions can offer to provide communities with CSR extension education programmes in order to increase their awareness and foster sustainable community development.

According to Authenticity Consulting (2016), there are many approaches to providing capacity building services. They include the following:

1) Providing access to repositories of information and resources (for example, databases, libraries and web sites)

2) Publications

3) Trainings (public, customized or on-line)

4) Consultation (for example, coaching, facilitating, expert advice and conducting

5) research)

6) Coordinating alliances

7) Some others include;

8) Board development

9) Business development

10) Collaboration planning

11) Conflict resolution

12) Financial management

13) Funding

14) Information technology

15) Leadership development

16) Legal Management development

17) Networking opportunities

18) Organizational development

19) Programme design

20) Project management

21) Quality management

22) Risk management

23) Strategic planning and Team building

\section{CONDITIONS THAT INFLUENCES COMMUNITY CAPACITY BUILDING}

Conditions that influence community capacity building are concerned with the mediating circumstances that could facilitate or inhibit community capacity and efforts to build it. Chaskins (2001), illustrates these conditions by arguing that a sense of community could be fostered by a local action such as encouraging residents to participate in problem-solving activities, trying to prevent a development deal in their region or trying to get a local recreation facility. Other factors can either support or inhibit the possibility of creating that sense of community. For example, residential stability and greater social capital can increase a sense of social cohesion and the likelihood of participation in local activities becomes greater. The existence of informal mechanisms of social control, institutional trust and a level of sense of safety, connected to stability and existence of viable social networks can provide a framework where a sense of community can be more easily cultivated.

However, there can also be negative conditioning influence. For example, there can be macro level influences (such as the structure of the regional economy, the influence of migration and racial and economic segregation, and the unequal distribution of resources among communities) that may restrict a particular community's ability to use or build its capacity. These conditions are generally not susceptible to neighbourhood actions and require intervention strategies and policy action at the municipal, provincial, or federal level to effect change. On the other hand, positive changes in these factors at certain times may provide a community with opportunities to take advantage of resources that were not previously available to help build capacities (Chaskins, 2001). 
Capacity Building for Community Awareness on Corporate Social Responsibility of Oil Companies for Sustainable

Community Development in Nigeria

\section{STEPS TO CAPACITY BUILDING FOR SUSTAINABLE COMMUNITY DEVELOPMENT}

In the UNDP's 2008-2013 "Strategic Plan for Development" capacity building is the " ... organisation's core contribution to development." It promotes a capacity building approach to development in the 166 countries it is active in. It focuses on building capacity on an institutional level and offers a 5step process for systematic capacity building. The steps as stated by UNDP (2018) are:

\subsection{ENGAGEMENT OF STAKEHOLDERS ON CAPACITY DEVELOPMENT}

An effective capacity building process must encourage participation by all those involved. If stakeholders are involved and share ownership in the process of development, they will feel more responsible for the outcome and sustainability of the development. Engaging stakeholder's who are directly affected by the situation allows for more effective decision-making; it also makes development work more transparent. UNDP and its partners use advocacy and policy advisory to better engage stakeholders.

\subsection{ASSESS CAPACITY NEEDS AND ASSETS}

Assessing pre-existing capacities through engagement with stakeholders allows capacity builders to see what areas require additional training, what areas should be prioritised, in what ways capacity building can be incorporated into local and institutional development strategies. UNDP argues that capacity building that is not rooted in a comprehensive study and assessment of the pre-existing conditions will be restricted to training alone, which will not facilitate sustained results.

\subsection{FORMULATE A CAPACITY DEVELOPMENT RESPONSE}

Once an assessment has been completed, a capacity building response must be created based on four core issues:

Institutional arrangements - Assessments often find that institutions are inefficient because of bad or weak policies, procedures, resource management, organisation, leadership, frameworks, and communication. UNDP and its networks work to solve problems associated with institutional arrangements by developing human resource frameworks covering policies and procedures for recruitment, deployment and transfer, incentives systems, skills development, performance evaluation systems, and ethics and values.

Leadership - UNDP believes that leadership by either an individual or an organisation can catalyse the achievement of development objectives. Strong leadership allows for easier adaption to changes, strong leaders can also influence people. It uses coaching and mentoring programmers to help encourage the development of leadership skills such as, priority setting, communication and strategic planning.

Knowledge - UNDP believes knowledge is the foundation of capacity. It believes greater investments should be made in establishing strong education systems and opportunities for continued learning and the development of professional skills. It supports the engagement in post-secondary education reforms, continued learning and domestic knowledge services.

Accountability - Implementation of accountability measures facilitates better performance and efficiency. A lack of accountability measures in institutions allows for the proliferation of corruption. UNDP promotes the strengthening of accountability frameworks that monitor and evaluate institutions. It also promotes independent organisations that oversee, monitor and evaluate institutions. It promotes the development of capacities such as literacy and language skills in civil societies that will allow for increased engagement in monitoring institutions.

\subsection{IMPLEMENT A CAPACITY DEVELOPMENT RESPONSE}

Implementing a capacity building programme involves the inclusion of multiple systems; national, local, institutional. It involves continual reassessment and expect change depending on changing situations. It includes evaluative indicators to measure the effectiveness of the initiated programmes. 


\subsection{EVALUATE CAPACITY DEVELOPMENT}

Evaluation of capacity building promotes accountability. Measurements is based on changes in an institution's performance. Evaluations are based on changes in performance based around the four main issues: institutional arrangements, leadership, knowledge, and accountability. It focuses on building capacity at the institutional level because it believes that "institutions are at the heart of human development, and that when they are able to perform better, sustain that performance over time, and manage 'shocks' to the system, they can contribute more meaningfully to the achievement of national human development goals."

\section{IMPORTANCE OF CAPACITY BUILDING FOR SUSTAINABLE COMMUNITY DEVELOPMENT}

It takes leaders of any community or nation time and effort to build capacity. It may also require the support of individuals with expertise and or money for training. Therefore, building community capacity leads to positive outcomes for sustainable community development. Some of the benefits as stated by Oyebamiji and Nwabueze (2020) are:

1) Capacity building promotes stronger community relationships; that is, healthier people, caring families and safer and welcoming communities

2) Increased number of community-based opportunities are identified

3) It enhances the ability of community members to share ideas on a course of action

4) Capacity building increase competence in setting and realising common goals

5) It expands community intuition in sensing what to do, when to do it and when to quit or leave

6) Capacity building enhances respect for limited resources including people so that shortages, duplication or waste are minimised

7) It promotes awareness of the importance of protecting, advocating for and improving the conditions for vulnerable people, distinct cultures, foundering economies and environment.

8) Building community capacity promotes skilled leadership

9) Capacity building promotes an increased interest for young people to be interested in aspiring to be leaders

10) Community capacity building increases ability to handle disappointments, threats and hazards to community pride and wellbeing

\section{CONCLUSION}

Corporate social responsibility of oil companies to their host communities is an integral aspect for ensuring sustainable community development programmes. Capacity building programmes such as townhall meetings, extension programmes, adult literacy programmes and information and communication technology provides opportunities for community members to increase their awareness on CSR related issues and this deserves adequate attention by all participating/relevant stakeholders in ensuring sustainable community development.

\section{SOURCES OF FUNDING}

This research received no specific grant from any funding agency in the public, commercial, or not-for-profit sectors.

\section{CONFLICT OF INTEREST}

The author have declared that no competing interests exist.

\section{ACKNOWLEDGMENT}

None. 
Capacity Building for Community Awareness on Corporate Social Responsibility of Oil Companies for Sustainable Community Development in Nigeria

\section{REFERENCES}

[1] Authenticity Consulting (2016). Non-profit Organisational Assessment. Accessed on 21st February, 2020 from https//:www.authenticityconsulting.org.

[2] Business News Daily (2018). Corporate social responsibility. Accessed on 4th February, 2020, from https//:www.businessnewsdaily.org.

[3] Carroll, A.B. (1991). The Pyramid of Corporate Social Responsibility: Toward the moral management of organisational stakeholders. Business Horizons, July-August, 39-48. Accessed 0n 31st January, 2020 from https//:www.scholar.google.com.

[4] Chaskin, R.J., 2001. Building community capacity: A definitional framework and case

[5] studies from a comprehensive community initiative. Urban Affairs Review, 36(3),

[6] 699-717.

[7] Craig, G. (2007). Community capacity building: Something old, something new...? Critical Social Policy. 27, 335-359.

[8] Frank, F. \& Smith, A. (2014). The community development handbook: A tool to build community capacity. Canada: Labour Market Learning and Development Unit, Human Resource Development.

[9] Goodman, R.M. Speers, M.A. \& McLeroy, K. (1998). Identifying and defining the dimensions of community capacity to provide a basis for measurement. Health Education and Behaviour, 25(3), 258-278.

[10] Laverack, G. \&Thangphet, S. (2009). Building community capacity for locally managed ecotourism in Northern Thailand, Community Development Journal, 44(22), 172-185.

[11] Lee, N. \& Kotler, P. (2013). Corporate social responsibility doing the most good for your company and your cause.

[12] Merinoa, S.S.\&Carmenadoa, I.R. (2012). Capacity building in development projects. Procedia - Social and Behavioural Science, 960-967.

[13] Oyebamiji, M.A. \& Nwabueze, N. (2020).Capacity building for improved community development participation of citizens in Nigeria. In M.A. Oyebamiji, E.O. Olajide, C.O. Omoregie and N.A. Adedokun, (Eds), Citizens' participation and good governance in Nigeria, Ibadan, Rasmed publications Limited,101 -129.

[14] Patrick, J.M. \& Ijah, C.N. (2017). Community capacity building for sustainable community development: a framework for urban indigenous communities. Nigerian community development journal, 6. 97-110.

[15] Rabinowitz, P. (2011). Encouraging leadership development across the life span community tool box. Work Group for Community Health and Development, University of Kansas, Lawrence, KS. Accessed on 21st February, 2020 from http://ctb.ku.edu/en/tablecontents/chapter_1013.aspx.

[16] Sheehy, B. (2014). "Anglo-American Directors' Legal Duties and CSR: Prohibited, Permitted or Prescribed?". Dalhousie Law Journal. Vol. 31.

[17] United Nations Development Programme (2011). Supporting Capacity Building: The UNDP approach. United Nations Development Programme. www.undp.org UNDP and Capacity Building.

[18] United Nations International Strategy for Disaster Reduction (UNISDR) (2016). Implementation of the Sendai Framework for Disaster Risk Reduction 2015-2030. Report of the Secretary General. Accessed on 21st February, 2020 from https://unisdr.org/files/resolutions/N1624116.pdf.

[19] Verity, F. (2007). Community Capacity Building - A review of the literature. Adelaide, South Australian Department of Health.

[20] Wildermeersch, D. (2014). Displacing concepts of social learning and democratic citizenship. In Biesta, M. D. \& Wildermeersch, D. (Eds.), Civic learning, democratic citizenship and the public sphere (pp. 15-28). Dordrecht, The Netherlands: Springe.

[21] World business council for sustainable development (2016). Accessed on 17thFebruary, 2020,from http://www.wbcsd.com. 